\title{
Effects of inulin, carrot and cellulose fibres on the properties of raw and fried chicken meatballs
}

\author{
O. Kılınççeker ${ }^{1 \#} \&$ Ş. Kurt ${ }^{2}$ \\ 1 Department of Food Processing, Technical Sciences Vocational School, University of Adıyaman, TR-02040, Adıyaman, \\ Turkey \\ ${ }^{2}$ Department of Food Engineering, Faculty of Engineering, University of Adıyaman, TR-02040, Adıyaman-Turkey
}

(Received 19 June 2017; Accepted 16 October 2017; First published online 8 November 2017)

\begin{abstract}
Copyright resides with the authors in terms of the Creative Commons Attribution 4.0 South African Licence.
See: http://creativecommons.org/licenses/by/4.0/za

Condition of use: The user may copy, distribute, transmit and adapt the work, but must recognise the authors and the South African Journal of Animal Science.
\end{abstract}

\begin{abstract}
The effects of inulin, carrot, and cellulose fibres $(3 \%, 6 \%$, and $9 \%)$ on raw and fried chicken meatballs were studied. Meatball $\mathrm{pH}$, thiobarbituric acid reactive substances (TBARS), and colour values were determined for raw samples in refrigerated storage on the 1st, 5th and 10th days. The effects of fibres and their various levels on frying characteristics such as yield, diameter reduction, moisture retention, fat absorption, colour and sensory properties of fried chicken meatballs were evaluated. Fibres caused significant differences in the $\mathrm{pH}$ and TBARS values of the raw meatballs owing to their sources and levels. They improved colour properties ( $L$ : lightness, $a$ : redness, $b$ : yellowness) of the raw and fried samples. In addition, cellulose and carrot fibres affected the yield, moisture absorption, and diameter reduction values of the fried samples positively. In conclusion, the use of fibres in such products can affect product quality positively. The use of $3 \%$ inulin, $9 \%$ carrot, and $6 \%$ and $9 \%$ cellulose fibres had more beneficial effects on chicken meatballs.
\end{abstract}

Keywords: Dietary fibre, frying, poultry products, product quality, storage stability

\# Corresponding author: okilincceker@adiyaman.edu.tr

\section{Introduction}

Dietary fibre has beneficial effects on human health owing to its functional properties such as regulating the activity of the large intestine. In recent years, consumers have started to focus on healthy foods, because of the increase in diabetes, cancer, cardiovascular diseases, and obesity. For this reason, food producers are making an effort to produce healthier foods, by trying to produce low-fat meat and poultry products to reduce calorie intake by using fibres (Kılınççeker, 2011; Cava et al., 2012; Santhi \& Kalaikannan, 2014; Tabarestani \& Tehrani, 2014). The use of non-meat ingredients such as fibre in chicken meat products can improve their functional properties, such as water-holding capacity and antioxidant characteristics.

Certain shape, texture, and colour problems in meat products may be seen during processing. In addition, oxidation and proteolytic deterioration of these products may occur during storage (Cava et al., 2012; Petracci et al., 2013). These problems can pose health risks to people. Additionally, they can cause financial losses for consumers and producers. However, the shelf life of meatballs and similar foods can be increased by reducing the degradation of fats and proteins. For these reasons, the use of additives, such as fibres, in preventing deterioration in meat products has been the topic of many studies (Khalil, 2000; McCarthy et al., 2001; Talukder \& Sharma, 2010; Castro et al., 2011; Ibrahim et al., 2011; Cava et al., 2012; Petracci et al., 2013).

Fibres are easily obtained from plant-derived materials such as polysaccharides, oligosaccharides, and lignin. They have many functions and activities (Dhingra et al., 2014). For example, depending on their physico-chemical properties, they can improve the colour, texture, and sensory properties of foods (Biswas et al., 2011). These fibres are low in cost and can be used in chicken meat products to increase frying efficiency and improve texture. Moreover, they can affect the sensory properties of these products positively. Fibres may have properties, depending on their types and sources, which can cause differences in foods. The use of the most appropriate fibre in food processing and storage is important for the final product quality 
(Petracci et al., 2013; Pinero et al., 2008; Sanchez-Zapata et al., 2010).

However, the influence of fibre on fried chicken meatballs has been studied by only a few researchers. The aim of this study was therefore to determine the effects of inulin, carrot, and cellulose fibres on certain frying and storage stability properties of chicken meatballs.

\section{Materials and methods}

Fibres of inulin (moisture $5 \%$, total fibre content $90 \%$, particle size $<250 \mu \mathrm{m}$ ), cellulose (moisture $7 \%$, total fibre content $92 \%$, particle size $<250 \mu \mathrm{m}$ ), and carrot (moisture $9 \%$, total fibre content $86 \%$, particle size $<250 \mu \mathrm{m}$ ) were obtained from Kimbiotek Co (Istanbul Turkey). Sunflower oil (Yudum, Yudum Co., Balıkesir, Turkey) was used as a frying medium. The chicken breast meat, without skin, and other ingredients were obtained from a local market in Adıyaman. A fryer (Tefal, FF1024, China) with a thermostatic heat control was used in the frying operations.

Chicken breast meats were kept at $-18^{\circ} \mathrm{C}$ in plastic bags (medium polyethylene). They were thawed at $4{ }^{\circ} \mathrm{C}$ for 18 hours and minced with a mincing machine (Tefal, Le Hachoir 1500). A sample of about $9700 \mathrm{~g}$ minced meat was kneaded with $150 \mathrm{~g}$ salt $(\mathrm{NaCl}), 50 \mathrm{~g}$ black pepper, and $100 \mathrm{~g}$ sunflower oil for $15 \mathrm{~min}$ and rested at $4{ }^{\circ} \mathrm{C}$ for $30 \mathrm{~min}$. This formulation was divided into 10 groups and various levels of each fibre were added to each, as presented in Figure 1. Thereafter, each group was re-kneaded for 1 min and shaped into meatballs by hand at equal weight $(20 \mathrm{~g})$ and diameter $(30 \mathrm{~mm})$. Then each group was divided into two. One set was used to determine storage stability, the other for frying. For storage stability, the raw meatballs were placed in polystyrene dishes, wrapped with stretch film, and stored at $4{ }^{\circ} \mathrm{C}$ for 10 days to determine $\mathrm{pH}$, TBARS (thiobarbituric acid reactive substances), and colour values on the 1st, 5th, and 10th days of storage. For frying, freshly prepared meatballs were fried using $1 \mathrm{~L}$ sunflower oil at $175^{\circ} \mathrm{C}$ for $5 \mathrm{~min}$ in a deep fryer (Tefal, FF1024, China) in order to determine the colour, yield, diameter reduction, moisture retention, fat absorption, and sensory properties. Ten meatballs were used in each analysis. A flow chart of the formulation and analyses of the chicken meatballs is presented in Figure 1.

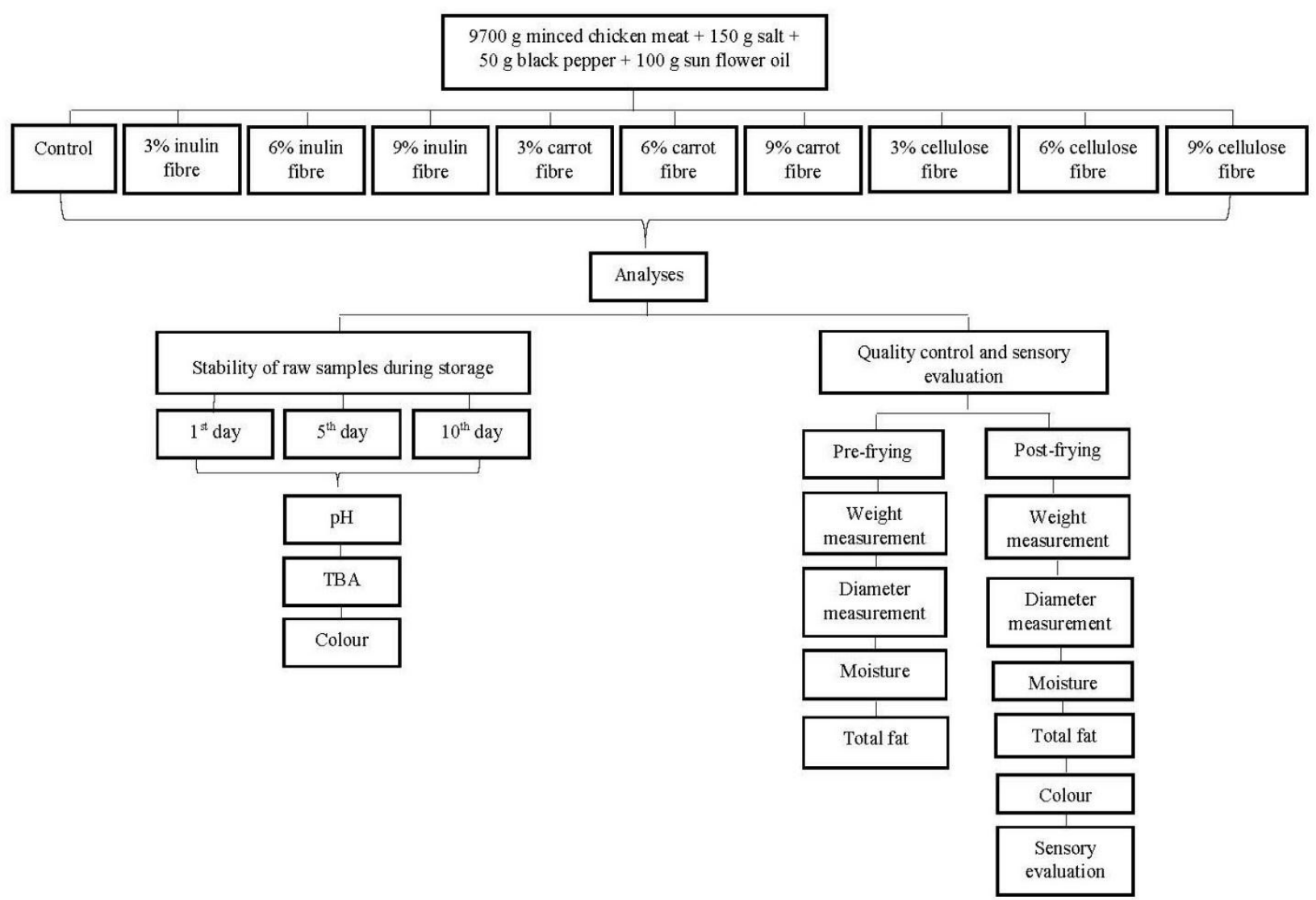

Figure 1 Flow chart of chicken meatball formulations and analyses 
Ten grams of sample were homogenized in $100 \mathrm{ml}$ deionized water for $1 \mathrm{~min}$ and $\mathrm{pH}$ was measured with a $\mathrm{pH}$ meter (Orion 3-Star, Thermo Fisher Scientific, Waltham, MA), as outlined by Ockerman (Ockerman, 1985). To determine the extent of oxidative rancidity of the samples after 1,5 , and 10 days of storage, TBARS values were determined as described by Tarladgis et al. (1960). For this purpose, the samples were blended in a commercial blender (Warning Commercial Blender), and then $10 \mathrm{~g}$ of the blended samples was mixed with $50 \mathrm{~mL}$ of $50{ }^{\circ} \mathrm{C}$ distilled water. The homogenate was quantitatively transferred to an $800-\mathrm{mL}$ Kjeldahl flask using $48 \mathrm{~mL}$ of $50{ }^{\circ} \mathrm{C}$ distilled water, containing $2 \mathrm{~mL}$ of $18 \% \mathrm{HCl}$. The resultant mixture was heated, and the first $50 \mathrm{~mL}$ of distillate was collected. Five milliliters of the distillate was added to $5 \mathrm{~mL}$ of TBA reagent, and heated in a boiling water bath for $35 \mathrm{~min}$. The absorbance was read at $538 \mathrm{~nm}$ (UV-160 A, UV-Visible Recording Spectrophotometer, Shimadzu, Tokyo, Japan) against a reagent blank. The TBARS numbers were expressed as $\mathrm{mg}$ of malonaldehyde/ $\mathrm{kg}$ samples.

Colour values were measured with a colorimeter (CR-400, Konica Minolta, Inc., Osaka, Japan) with illuminant D65, $2^{\circ}$ observer, Diffuse/O mode, $8-\mathrm{mm}$ aperture of the instrument for illumination and $8 \mathrm{~mm}$ for measurement. The measurements were calibrated with a white reference tile after the $L$, $a$, and $b$ measurement functions of the device ad been selected. Colour was described according to CIELAB system as $L, a$, and $b$ values (Dogan, 2006). Four meatballs of each sample were used for the analysis and three replicate measurements were taken on the surface of each meatball.

To calculate the frying yield and diameter reduction values, the weight and diameter of meatballs, before and after frying, were measured according to Equations (1) and (2):

Frying yield $(\%)=\frac{\text { cooked meatball weight }}{\text { raw meatball weight }} \times 100$

Diameter reduction $(\%)=\frac{\text { raw meatball diameter }- \text { cooked meatball diameter }}{\text { raw meatball diameter }} \times 100$

The moisture content of raw and cooked samples was determined at $105 \pm 2{ }^{\circ} \mathrm{C}$ by oven air method and the fat content was evaluated by using the Soxhlet extraction method with n-hexane (AOAC, 2002). Then, moisture retention and fat absorption values were calculated according to Equations (3) and (4) (Soltanizadeh \& Ghiasi-Esfahani, 2015):

Moisture retention $(\%)=\frac{\text { moisture in cooked meatball }(\%)}{\text { moisture in raw meatball (\%) }} \times$ frying yield

Fat absorbtion (\%) = fat in cooked meatball (\%) - fat in raw meatball (\%)

Fried chicken meatballs were served in random order to a ten-member trained panel of graduate students from the Department of Food Processing at Adıyaman University two minutes after frying for sensory analyses. The panellists assessed the sensory properties with a hedonic scale for appearance, colour, odour, taste, texture, and acceptability. The values in the scale indicated these reactions, namely $1=$ dislike very much to $9=$ like very much (Gokalp et al., 1999).

The experimental procedure was designed as two repetitions and three parallels. As a factorial design, three levels $(3,6$, and $9 \%)$ of three factors (inulin, carrot, and cellulose) were studied in three storage times (1st, 5th, 10th days). The data were subjected to analysis of variance (ANOVA). When there were differences among the samples, the differences were compared with Duncan's multiple-range tests; a probability value of $P<0.05$ was considered significant.

\section{Results and discussion}

The effects of fibres were found to be significant on the physico-chemical properties of raw meatballs. As shown in Table 1, the $\mathrm{pH}$ values of meatballs changed with each fibre. The effects of carrot fibre on the $\mathrm{pH}$ values were found to be higher than those of inulin and cellulose fibres. The addition of carrot fibre decreased the $\mathrm{pH}$ values; in particular, the effect of increasing carrot fibre concentration was found to be significant $(P<0.05)$. The acidic nature of carrot might have decreased the $\mathrm{pH}$ values of the samples. However, the increased concentration of inulin and cellulose decreased $\mathrm{pH}$ values irregularly on the 10th day. Moreover, $\mathrm{pH}$ values of samples decreased with increasing storage time. $\mathrm{pH}$ values may have been affected by the microbial activity of raw meatballs during storage. Kılınççeker (2017) reported that tara, taragakant, and agar gums had significant effects on the $\mathrm{pH}$ values of chicken meatballs. However, Sanchez-Zapata et al. (2010) stated that the effects of various levels of tigernut fibre on pork burger did not cause differences. They reported that the $\mathrm{pH}$ values of burgers changed in the range of 6.16 to 6.20 . 
Similarly, Demirci et al. (2014) reported that the pH values of uncooked and cooked meatballs with different gums changed in the range of 6.7 to 6.9. YIlmaz (2004) determined that the $\mathrm{pH}$ value of meatballs with 5,10 , 15 , and $20 \%$ rye bran ranged from 6.02 to 6.09 . They have also determined the highest pH values from $10 \%$ and $20 \%$ rye bran. The authors found lower $\mathrm{pH}$ values (Table 1 ) than in this study due to the use of different fibres.

The effects of fibres on the meatballs were found to be significant on lipid oxidation stability. TBARS is an important parameter to determine lipid oxidation of meat products. The TBARS values of meatballs with inulin $(6 \%$ and $9 \%)$ were found to be lower than those with cellulose and carrot, respectively (Table 1). Moreover, TBARS values of samples with inulin $(6 \%$, 5 th day) were lower than carrot and cellulose fibres at the same concentration. Increased carrot concentration increased TBARS values at the 5th day. However, higher concentrations of inulin and carrot fibres increased TBARS values at the 10th day. The TBARS values of samples with each fibre increased in the last days of storage. Serdaroğlu et al. (2005) reported that TBARS values of low-fat meatballs with legume flours were in the range of 0.67 to $0.82 \mathrm{mg} / \mathrm{kg}$ at day 0 and 1.99 to $2.55 \mathrm{mg} / \mathrm{kg}$ at the $3 \mathrm{rd}$ month at storage at $-18^{\circ} \mathrm{C}$. They stated that at the end of storage, the TBARS values of the meatballs were within the consumption limits. Furthermore, Cava et al. (2012) reported that tomato fibre and beetroot fibre reduced lipid oxidation of chicken products. Moreover, oxidation had a relationship with the level of fibres. They found TBARS values in the range of 2.03 to $3.82 \mathrm{mg} / \mathrm{kg}$ at the 10th day of storage $\left(4{ }^{\circ} \mathrm{C}\right)$. Generally, TBARS values of raw meatballs were at an acceptable level of consumption, as provided by Gokalp et al. (1999), ranging from 0.7 to $1 \mathrm{mg} / \mathrm{kg}$. In addition, TBARS values were found to be lower than the values of Schormüller (1969) at the end of storage.

The results of the colour analysis showed that the effects of fibres on $L, a$ and $b$ were significant (Table 1). As shown in Table 1, the addition of fibres increased the $L$ values of the samples. The $L$ values of meatballs with cellulose fibre $(6 \%$ and $9 \%$, at 1 st and 10 th days, respectively) were higher than meatballs with carrot fibre and inulin at the same concentrations and same storage times. Moreover, the $L$ values of samples with cellulose fibre (3\%) were higher than samples with carrot fibre $(3 \%)$ and inulin $(3 \%)$ at the 5 th day. The effects of storage time decreased the $L$ values of the samples with carrot fibre at $3 \%$ and $6 \%$ levels. However, storage time decreased the $L$ values of the samples with $9 \%$ cellulose fibre. The addition of fibres increased the $a$ and $b$ values of the sample (Table 1). The $a$ and $b$ values of meatballs with carrot fibre were found to be higher than those of meatballs with cellulose or inulin. The effects of storage time on the a values of the samples were found to be significant at the 10th day. Storage time decreased the a values of the samples. However, the effects of storage time on the $b$ values of samples containing inulin or carrot fibres were significant.

The colours of raw chicken meatballs would be affected by the natural colours of fibres. In addition, oxidation might affect the colours during storage (Kılınççeker, 2017). Cava et al. (2012) reported that the $L$ value was significantly lower in a chicken product with tomato and beetroot $(3 \%)$ fibres than in the control and inulin ones. Moreover, inulin (1\% and $2 \%)$ and beetroot fibre $(1 \%$ and $2 \%)$ increased the $L$ values. In addition, tomato fibre increased the a value, while inulin and beetroot fibre lowered the a value compared with control and those with tomato fibre. Additionally, beetroot fibre and tomato fibre at $1 \%$ and $3 \%$ concentrations increased $b$ values compared with the control, while inulin created changes in the yellowness of raw chicken meat products. They found colour values of meatballs in the ranges of 47.7 to 67.8 for $L, 0.6$ to 13.5 for $a$, and 5.7 to 33.7 for $b$. In the current study, the $L$, $a$ and $b$ values were lower than in Cava et al.'s (2012) study. These differences were associated with the types and levels of fibre added to the sample. Aleson-Carbonel et al. (2005) reported that the inclusion of fibre from citrus fruit (lemon albedo) also affected colour values of beef burgers.

The effects of fibres on the instrumental colour values of fried chicken meatballs were found to be significant. As shown in Table 2 , the $L$ values of fried chicken meatballs increased with cellulose and decreased with inulin. The $L$ values of samples with cellulose were found to be higher than samples with carrot fibre or inulin at the same concentrations (6\% and $9 \%)$. Fibres increased the a values of sample. In particular, increasing inulin concentration heightened the a values (Table 2). Moreover, in the study the $a$ values of samples with inulin were higher than those of carrot and cellulose. The effects of $6 \%$ inulin and $6 \%$ carrot fibres on the $b$ values were found to be significant (Table 2). The $b$ value of the sample with $6 \%$ fibre was found to be high in cellulose, carrot and inulin, respectively. Kilincceker \& Yilmaz (2016) reported that the natural colour of fibres plays an important role in the colour of fried chicken meatballs. The authors stated that pea and oat fibres increased the lightness of the samples. They also determined that the addition of wheat and apple fibres increased the $a$ values and pea fibre increased the $b$ values of fried chicken meatballs. Similarly, Yılmaz (2004) reported that $20 \%$ rye bran increased the $L$ values of meatballs. 


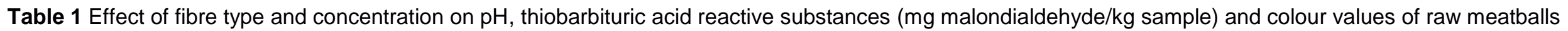
at different storage periods

\begin{tabular}{|c|c|c|c|c|c|c|c|c|c|c|c|c|c|}
\hline & \multirow{3}{*}{$\begin{array}{l}\text { Fibre } \\
\text { type }\end{array}$} & \multicolumn{4}{|c|}{ 1st day } & \multicolumn{4}{|c|}{ 5th day } & \multicolumn{4}{|c|}{ 10th day } \\
\hline & & \multicolumn{4}{|c|}{ Fibre concentration } & \multicolumn{4}{|c|}{ Fibre concentration } & \multicolumn{4}{|c|}{ Fibre concentration } \\
\hline & & Control (0\%) & $3 \%$ & $6 \%$ & $9 \%$ & Control (0\%) & $3 \%$ & $6 \%$ & $9 \%$ & Control (0\%) & $3 \%$ & $6 \%$ & $9 \%$ \\
\hline \multirow{4}{*}{$\mathrm{pH}$} & Inulin & $6.04^{\mathrm{aAX}}$ & $6.06^{\mathrm{aAX}}$ & $6.05^{\mathrm{aAX}}$ & $6.08^{\mathrm{aAX}}$ & $5.93^{\mathrm{aAY}}$ & $5.94^{\mathrm{aAY}}$ & $5.95^{\mathrm{aAY}}$ & $5.95^{\mathrm{aAY}}$ & $5.79^{\mathrm{aAZ}}$ & $5.73^{\mathrm{bCz}}$ & $5.75^{\mathrm{aBCZ}}$ & $5.77^{\mathrm{aABZ}}$ \\
\hline & Carrot & $6.04^{\mathrm{aAX}}$ & $5.99^{\mathrm{bABX}}$ & $5.97^{\mathrm{bBX}}$ & $5.89^{\mathrm{cCX}}$ & $5.93^{\mathrm{aAY}}$ & $5.90^{\mathrm{bAY}}$ & $5.84^{\mathrm{bBY}}$ & $5.81^{\mathrm{bBY}}$ & $5.79^{\mathrm{aAZ}}$ & $5.72^{\mathrm{cBZ}}$ & $5.66^{\mathrm{bCz}}$ & $5.64^{\mathrm{bDZ}}$ \\
\hline & Cellulose & $6.04^{\mathrm{aBX}}$ & $6.06^{\mathrm{aAX}}$ & $6.03^{\mathrm{abBX}}$ & $6.04^{\mathrm{bBX}}$ & $5.93^{\mathrm{aAY}}$ & $5.96^{\mathrm{aAY}}$ & $5.94^{\mathrm{aAY}}$ & $5.94^{\mathrm{aAY}}$ & $5.79^{\mathrm{aAZ}}$ & $5.79^{\mathrm{aABZ}}$ & $5.77^{\mathrm{aBZ}}$ & $5.78^{\mathrm{aABZ}}$ \\
\hline & Inulin & $0.25^{\mathrm{aAY}}$ & $0.23^{\mathrm{aAY}}$ & $0.26^{\mathrm{aAY}}$ & $0.25^{\mathrm{aAY}}$ & $0.26^{\mathrm{aAY}}$ & $0.24^{\mathrm{aAY}}$ & $0.24^{\mathrm{bAZ}}$ & $0.26^{\mathrm{bAY}}$ & $0.38^{\mathrm{aBX}}$ & $0.39^{\mathrm{aBX}}$ & $0.38^{\mathrm{bBX}}$ & $0.43^{\mathrm{aAX}}$ \\
\hline \multirow{3}{*}{ TBARS } & Carrot & $0.25^{\mathrm{aAY}}$ & $0.26^{\mathrm{aAY}}$ & $0.29^{\mathrm{aAY}}$ & $0.32^{\mathrm{aAY}}$ & $0.26^{\mathrm{aBY}}$ & $0.28^{\mathrm{aABY}}$ & $0.31^{\mathrm{aABY}}$ & $0.35^{\mathrm{aAY}}$ & $0.38^{\mathrm{acx}}$ & $0.40^{\mathrm{aBCX}}$ & $0.42^{\mathrm{aBX}}$ & $0.51^{\mathrm{aAX}}$ \\
\hline & Cellulose & $0.25^{\mathrm{aAY}}$ & $0.27^{\mathrm{aAY}}$ & $0.26^{\mathrm{aAY}}$ & $0.25^{\mathrm{aAY}}$ & $0.26^{\mathrm{aAY}}$ & $0.28^{\mathrm{aAY}}$ & $0.27^{\mathrm{abAY}}$ & $0.28^{\mathrm{bAY}}$ & $0.38^{\mathrm{aAX}}$ & $0.40^{\mathrm{aAX}}$ & $0.39^{\mathrm{aAX}}$ & $0.44^{\mathrm{aAX}}$ \\
\hline & Inulin & $40.49^{\mathrm{aBX}}$ & $44.35^{\mathrm{aBX}}$ & $44.64^{\mathrm{bBX}}$ & $49.06^{\mathrm{bAX}}$ & $40.30^{\mathrm{aDx}}$ & $43.81^{\mathrm{bCX}}$ & $48.14^{\mathrm{bBX}}$ & $50.41^{\mathrm{aAX}}$ & $41.22^{\mathrm{aBX}}$ & $42.65^{\mathrm{aBX}}$ & $47.81^{\mathrm{bAX}}$ & $51.75^{\mathrm{aAX}}$ \\
\hline \multirow[t]{3}{*}{$L$} & Carrot & $40.49^{\mathrm{aCX}}$ & $47.27^{\mathrm{aBX}}$ & $46.70^{\mathrm{abBX}}$ & $50.15^{\mathrm{abAX}}$ & $40.30^{\mathrm{aBX}}$ & $43.49^{\mathrm{bBY}}$ & $42.92^{\mathrm{CBY}}$ & $49.70^{\mathrm{aAX}}$ & $41.22^{\mathrm{aBX}}$ & $41.54^{\mathrm{aABZ}}$ & $40.78^{\mathrm{cCZ}}$ & $45.35^{\mathrm{bAX}}$ \\
\hline & Cellulose & $40.49^{\mathrm{aCx}}$ & $48.56^{\mathrm{aBX}}$ & $54.47^{\mathrm{aAX}}$ & $58.19^{\mathrm{aAX}}$ & $40.30^{\mathrm{aDX}}$ & $47.98^{\mathrm{aCx}}$ & $52.61^{\mathrm{aBX}}$ & $55.92^{\mathrm{aAXY}}$ & $41.22^{\mathrm{aBX}}$ & $46.27^{\mathrm{aABX}}$ & $52.13^{\mathrm{aAX}}$ & $53.67^{\mathrm{aAY}}$ \\
\hline & Inulin & $2.00^{\mathrm{aBX}}$ & $2.17^{\mathrm{bABX}}$ & $2.25^{\mathrm{bABX}}$ & $2.66^{\mathrm{cAX}}$ & $1.93^{\mathrm{aBX}}$ & $2.23^{\mathrm{bABX}}$ & $2.44^{\mathrm{bAX}}$ & $2.54^{\mathrm{bAX}}$ & $0.80^{\mathrm{aCY}}$ & $1.02^{\mathrm{aBCY}}$ & $1.24^{\mathrm{aBY}}$ & $1.66^{\mathrm{bAY}}$ \\
\hline \multirow[t]{3}{*}{$a$} & Carrot & $2.00^{\mathrm{aBX}}$ & $3.37^{\mathrm{aAX}}$ & $3.48^{\mathrm{aAX}}$ & $3.90^{\mathrm{aAX}}$ & $1.93^{\mathrm{acx}}$ & $3.02^{\mathrm{aBX}}$ & $2.90^{\mathrm{aBX}}$ & $3.71^{\mathrm{aAX}}$ & $0.80^{\mathrm{aCY}}$ & $1.50^{\mathrm{aBY}}$ & $1.74^{\mathrm{aBY}}$ & $2.75^{\mathrm{aAY}}$ \\
\hline & Cellulose & $2.00^{\mathrm{aBX}}$ & $2.81^{\mathrm{abAX}}$ & $3.09^{\mathrm{abAX}}$ & $3.18^{\mathrm{bAX}}$ & $1.93^{\mathrm{aCx}}$ & $2.63^{\mathrm{abBX}}$ & $2.95^{\mathrm{aAX}}$ & $2.82^{\mathrm{bABXY}}$ & $0.80^{\mathrm{aBY}}$ & $1.52^{\mathrm{aAY}}$ & $1.82^{\mathrm{aAY}}$ & $2.02^{\mathrm{abAY}}$ \\
\hline & Inulin & $8.24^{\mathrm{aBX}}$ & $9.58^{\mathrm{aABX}}$ & $9.83^{\mathrm{bABX}}$ & $10.85^{\mathrm{cAZ}}$ & $8.41^{\mathrm{aDX}}$ & $9.81^{\mathrm{bCX}}$ & $10.67^{\mathrm{bBX}}$ & $11.33^{\mathrm{bAY}}$ & $8.60^{\mathrm{aBX}}$ & $9.24^{\mathrm{aBX}}$ & $10.65^{\mathrm{bABX}}$ & $11.94^{\mathrm{CAX}}$ \\
\hline \multirow[t]{2}{*}{$b$} & Carrot & $8.24^{\mathrm{aDX}}$ & $12.76^{\mathrm{aCx}}$ & $13.68^{\mathrm{aBX}}$ & $14.99^{\mathrm{aAX}}$ & $8.41^{\mathrm{acx}}$ & $11.64^{\mathrm{aBY}}$ & $12.03^{\mathrm{aBY}}$ & $14.86^{\mathrm{aAX}}$ & $8.60^{\mathrm{acx}}$ & $10.33^{\mathrm{aBZ}}$ & $10.99^{\mathrm{abBZ}}$ & $14.16^{\mathrm{aAX}}$ \\
\hline & Cellulose & $8.24^{\mathrm{acx}}$ & $11.08^{\mathrm{aBX}}$ & $13.25^{\mathrm{aABX}}$ & $13.57^{\mathrm{bAX}}$ & $8.41^{\mathrm{aDX}}$ & $11.22^{\mathrm{aCX}}$ & $12.50^{\mathrm{aBX}}$ & $13.23^{\mathrm{abAX}}$ & $8.60^{\mathrm{aBX}}$ & $10.96^{\mathrm{aABX}}$ & $12.63^{\mathrm{aAX}}$ & $13.16^{\mathrm{bAX}}$ \\
\hline
\end{tabular}

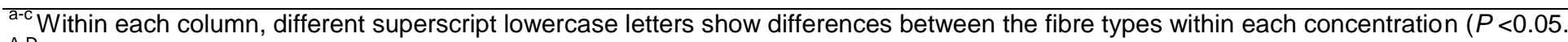

A-D Within each row, different superscript uppercase letters show differences between the fibre concentrations within each storage period $(P<0.05)$

${ }^{\mathrm{x}-\mathrm{z}}$ Within each row, different superscript uppercase letters show differences between the storage periods with respect to same fibre type and concentration $(P<0.05)$ 
In addition, YIImaz (2004) reported that the addition of rye bran increased the $b$ values, but decreased the $a$ values of cooked meatballs. However, Yaşarlar et al. (2007) reported that meatballs with bran had lower $L, a$, and $b$ values than control samples.

Table 2 Effect of fibre type and concentration on colour properties of fried meatballs

\begin{tabular}{|c|c|c|c|c|c|}
\hline & \multirow{2}{*}{ Fibre type } & \multicolumn{4}{|c|}{ Fibre concentration } \\
\hline & & Control (0\%) & $3 \%$ & $6 \%$ & $9 \%$ \\
\hline \multirow{4}{*}{$L$} & Inulin & $52.47^{\mathrm{aA}}$ & $49.37^{\mathrm{baB}}$ & $47.00^{\mathrm{bB}}$ & $42.31^{b c}$ \\
\hline & Carrot & $52.47^{\mathrm{aA}}$ & $52.19^{\mathrm{aA}}$ & $49.86^{\mathrm{bA}}$ & $50.22^{\mathrm{bA}}$ \\
\hline & Cellulose & $52.47^{\mathrm{aB}}$ & $54.71^{\mathrm{aB}}$ & $59.52^{\mathrm{aAB}}$ & $62.68^{\mathrm{aA}}$ \\
\hline & Inulin & $3.39^{\mathrm{aD}}$ & $5.91^{\mathrm{aC}}$ & $8.36^{\mathrm{aB}}$ & $10.12^{\mathrm{aA}}$ \\
\hline \multirow[t]{3}{*}{$a$} & Carrot & $3.39^{\mathrm{aB}}$ & $5.30^{\mathrm{abB}}$ & $7.34^{\mathrm{aA}}$ & $7.70^{\mathrm{bA}}$ \\
\hline & Cellulose & $3.39^{\mathrm{aB}}$ & $4.66^{\mathrm{bA}}$ & $4.78^{\mathrm{bA}}$ & $4.41^{\mathrm{CA}}$ \\
\hline & Inulin & $19.90^{\mathrm{aA}}$ & $20.54^{\mathrm{aA}}$ & $20.78^{\mathrm{bA}}$ & $19.48^{\mathrm{aA}}$ \\
\hline \multirow[t]{2}{*}{$b$} & Carrot & $19.90^{\mathrm{aA}}$ & $21.38^{\mathrm{aA}}$ & $21.58^{\mathrm{abA}}$ & $21.46^{\mathrm{aA}}$ \\
\hline & Cellulose & $19.90^{\mathrm{aA}}$ & $21.12^{\mathrm{aA}}$ & $22.90^{\mathrm{aA}}$ & $22.61^{\mathrm{aA}}$ \\
\hline
\end{tabular}

\footnotetext{
${ }^{\mathrm{a}-\mathrm{c}}$ Within each column, different superscript lowercase letters show differences between the fibre types within each concentration $(P<0.05)$

A-D Within each row, different superscript uppercase letters show differences between the concentrations within each fibre $(P<0.05)$
}

Reduced frying yield and diameter values are the result of the denaturation of meat proteins with loss of water and absorption of fat. They are important in maintaining the quality level of meatballs and are affected by the fat absorption and water-holding capacities of fibres (Cava et al., 2012). These values of chicken meatballs are shown in Table 3. Aside from inulin, it was understood that the addition of fibres increased yield values. Increasing inulin levels decreased the frying yield values. The yield value was highest in meatballs containing 3\% carrot. In addition, the frying process can affect the dimensions of samples, as shown in Table 3. However, carrot fibre prevented the diameter reduction of fried meatballs. The effects of cellulose and carrot fibres on the diameter of samples were better than those of inulin at $6 \%$ and $9 \%$ concentration levels. Kilincceker and Yilmaz (2016) reported that higher frying yields were determined in fried chicken meatballs with $5 \%$ oat fibre, $5 \%$ wheat fibre, $5 \%$ pea fibre, $5 \%$ apple fibre, and $5 \%$ lemon fibre. Talukder \& Sharma (2010) reported that the cooking yield of chicken meat patties prepared with wheat bran and oat bran was affected by the bran type, and the cooking yield rose as the bran content $(0,5,10$, and $15 \%)$ increased. Cava et al. (2012) reported that tomato fibre (1\% to $3 \%$ ) reduced cooking loss in cooked chicken products. Similar results were found by Sanchez-Zapata et al. (2010) in pork burgers with tigernut fibre. Samples with tigernut fibre had higher cooking yield than control. Sanchez-Zapata et al. (2010) reported that tigernut fibre decreased the diameter reduction values of pork burger. Similarly, Mansour and Khalil (1997) found that wheat fibre decreased the diameter reduction values compared with control. Kurt \& Kılınççeker (2012) also found that cereal and legume flour decreased the diameter reduction values of beef patties.

The frying process causes water evaporation in the meatballs. However, this change facilitates fat absorption. The fibres can retain water and form a barrier against fat absorption (Kılınççeker \& Kurt, 2010). Moisture retention and fat absorption values are summarized in Table 3 . Moisture retention of samples during the frying process was not affected significantly by the addition of cellulose (Table 3). However, the addition of inulin and $9 \%$ carrot fibre decreased the moisture contents of the samples. The effects of cellulose and carrot fibres on moisture retention values were better than inulin. In contrast to moisture retention, fat absorption was lower in meatballs with carrot fibre than others. The addition of inulin and cellulose fibres increased fat absorption values significantly (Table 3 ). However, the effects of carrot and cellulose fibres on the fat absorption values were better than inulin, in particular $9 \%$ carrot fibres. Pinero et al. (2008) reported that the addition of $13.45 \%$ oat fibre in beef patties increased moisture retention. Serdaroğlu (2006) reported that samples with oat flour had higher moisture retention values than control. Similar results were observed by Kurt and Kılınççeker (2012) and Ulu (2006) for moisture retention. 
Sanchez-Zapata et al. (2010) determined that tigernut fibre affected the moisture retention of pork burgers. Also, they stated that the addition of $15 \%$ fibre had higher moisture retention values than $5 \%$ and $10 \%$ fibre in burgers. Yaşarlar et al. (2007) reported that $20 \%$ rye bran caused a decrease in fat content compared with control. Mansour \& Khalil (1997) found that cooked beef burgers with wheat fibres had lower fat content than control. Santhi \& Kalainkannan (2014) stated that increased levels of oat flour in cooked chicken nuggets caused a decrease in the percentage of fat.

Table 3 Effects of fibre type and concentration on technological properties of fried meatballs

\begin{tabular}{llcccc}
\hline \multirow{2}{*}{$\begin{array}{l}\text { Technological } \\
\text { properties }\end{array}$} & $\begin{array}{l}\text { Fibre } \\
\text { type }\end{array}$ & Control(0\%) & $3 \%$ & $6 \%$ & $9 \%$ \\
\cline { 3 - 5 } & & $83.03^{\mathrm{aA}}$ & $77.79^{\mathrm{bB}}$ & $76.57^{\mathrm{bB}}$ & $68.72^{\mathrm{cC}}$ \\
Frying yield & Inulin & $83.03^{\mathrm{aB}}$ & $87.95^{\mathrm{aA}}$ & $84.29^{\mathrm{aB}}$ & $83.03^{\mathrm{bB}}$ \\
$(\%)$ & Carrot & $83.03^{\mathrm{aB}}$ & $86.09^{\mathrm{aA}}$ & $85.39^{\mathrm{aA}}$ & $86.00^{\mathrm{aA}}$ \\
& Cellulose & $2.93^{\mathrm{aA}}$ & $4.89^{\mathrm{aA}}$ & $6.11^{\mathrm{aA}}$ & $7.78^{\mathrm{aA}}$ \\
Diameter & Inulin & $2.93^{\mathrm{aA}}$ & $-0.02^{\mathrm{aB}}$ & $0.00^{\mathrm{bB}}$ & $0.00^{\mathrm{bB}}$ \\
reductions (\%) & Carrot & $2.93^{\mathrm{aA}}$ & $1.63^{\mathrm{aA}}$ & $-0.05^{\mathrm{bA}}$ & $0.00^{\mathrm{bA}}$ \\
& Cellulose & $74.17^{\mathrm{aA}}$ & $65.18^{\mathrm{bB}}$ & $63.46^{\mathrm{bB}}$ & $52.74^{\mathrm{bC}}$ \\
Moisture retention & Inulin & $74.17^{\mathrm{aA}}$ & $79.53^{\mathrm{aA}}$ & $73.90^{\mathrm{aA}}$ & $67.32^{\mathrm{aB}}$ \\
values $(\%)$ & Carrot & $74.17^{\mathrm{aA}}$ & $76.69^{\mathrm{aA}}$ & $74.78^{\mathrm{aA}}$ & $74.09^{\mathrm{aA}}$ \\
& Cellulose & $3.26^{\mathrm{aC}}$ & $5.24^{\mathrm{aB}}$ & $5.92^{\mathrm{aA}}$ & $6.24^{\mathrm{aA}}$ \\
Fat absorption & Inulin & $3.26^{\mathrm{aAB}}$ & $3.53^{\mathrm{bA}}$ & $3.30^{\mathrm{bA}}$ & $2.80^{\mathrm{cB}}$ \\
values $(\%)$ & Carrot & $3.26^{\mathrm{aB}}$ & $3.88^{\mathrm{bA}}$ & $3.42^{\mathrm{bB}}$ & $4.03^{\mathrm{bA}}$
\end{tabular}

${ }^{a-c}$ Within each column, different superscript lowercase letters show differences between the fibre types within each concentration $(P<0.05)$

${ }_{A-C}$ Within each row, different superscript uppercase letters show differences between the concentrations within each fibre $(P<0.05)$

The effects of fibres on the sensory quality of fried chicken meatballs were found to be significant, as shown in Table 4. The appearance score was highest with 3\% inulin. The effect of fibre types was not found to be significant at the same concentrations without $3 \%$. The addition of carrot and cellulose (3\%) fibres decreased appearance values. The addition of carrot, inulin (9\%) and cellulose (3\% and $9 \%)$ decreased the colour values of the samples (Table 4). The colour values of samples with $3 \%$ and $6 \%$ inulin were higher than carrot and cellulose fibres at the same concentration.

Odour scores of the samples decreased with more than $3 \%$ carrot fibres (Table 4). However, different concentrations of inulin and cellulose did not affect odour scores significantly. The effects of inulin on the taste values of samples were not significant. However, carrot and cellulose fibres decreased taste values (Table 4). The effects of inulin and cellulose fibres on taste scores were greater than carrot fibre at the same concentration. Although the addition of carrot and cellulose decreased the texture values of the samples, the effects of inulin addition were not found to be significant (Table 4). The texture scores of the samples with inulin or cellulose fibres (6\% and $9 \%)$ were higher than samples with carrot fibre at the same concentrations.

The acceptability of the samples with $3 \%$ inulin was highest, as shown in Table 4 . The addition of carrot decreased acceptability values. Moreover, $3 \%$ and $9 \%$ cellulose fibre decreased acceptability values of the samples. The acceptability scores of the samples with inulin and cellulose fibres were higher than those of carrot fibre at the same concentrations (6\% and $9 \%)$.

Appearance and colour can change the attractiveness of foods and affect consumer preference. These properties of chicken meatballs can be influenced by the natural colour of the fibres (Kilincceker \& Yilmaz 2016). Santhi \& Kalaikannan (2014) reported that increased addition of oat flour decreased some sensory properties of chicken nuggets. Mansour \& Khalil (1997) stated that fibre types were significant in cooked beef burgers, whereas wheat fibre levels were not significant. Sanchez-Zapata et al. (2010) reported that tigernuts $(0,5,10$, and $15 \%)$ did not cause significant differences in pork burger $(0,5,10$, and $15 \%$ of level). Pinero et al. (2008) reported that the addition of oat soluble fibre did not affect the appearance, 
tenderness and colour of beef patties.

Table 4 Effects of fibre type and concentration on sensory properties of fried meatballs

\begin{tabular}{lccccc}
\hline Sensory & Fibre & \multicolumn{4}{l}{ Fibre concentration } \\
\cline { 3 - 6 } properties & type & Control(0\%) & $3 \%$ & $6 \%$ & $9 \%$ \\
\hline \multirow{4}{*}{ Appearance } & Inulin & $7.50^{\mathrm{aAB}}$ & $8.00^{\mathrm{aA}}$ & $7.60^{\mathrm{aAB}}$ & $6.45^{\mathrm{aB}}$ \\
& Carrot & $7.50^{\mathrm{aA}}$ & $6.75^{\mathrm{bB}}$ & $6.50^{\mathrm{aB}}$ & $6.70^{\mathrm{aB}}$ \\
& Cellulose & $7.50^{\mathrm{aA}}$ & $6.70^{\mathrm{bB}}$ & $7.45^{\mathrm{aA}}$ & $6.60^{\mathrm{aB}}$ \\
Colour & Inulin & $7.35^{\mathrm{aA}}$ & $7.75^{\mathrm{aA}}$ & $7.75^{\mathrm{aA}}$ & $5.95^{\mathrm{aB}}$ \\
& Carrot & $7.35^{\mathrm{aA}}$ & $6.90^{\mathrm{abB}}$ & $5.90^{\mathrm{bD}}$ & $6.40^{\mathrm{aC}}$ \\
& Cellulose & $7.35^{\mathrm{aA}}$ & $5.90^{\mathrm{bB}}$ & $7.30^{\mathrm{abA}}$ & $6.15^{\mathrm{aAB}}$ \\
Odour & Inulin & $7.30^{\mathrm{aA}}$ & $7.10^{\mathrm{aA}}$ & $7.20^{\mathrm{aA}}$ & $6.80^{\mathrm{aA}}$ \\
& Carrot & $7.30^{\mathrm{aA}}$ & $6.75^{\mathrm{aA}}$ & $5.60^{\mathrm{bB}}$ & $5.45^{\mathrm{bB}}$ \\
& Cellulose & $7.30^{\mathrm{aA}}$ & $7.05^{\mathrm{aA}}$ & $7.25^{\mathrm{aA}}$ & $6.75^{\mathrm{aA}}$ \\
Taste & Inulin & $7.35^{\mathrm{aA}}$ & $7.45^{\mathrm{aA}}$ & $7.40^{\mathrm{aA}}$ & $6.65^{\mathrm{aA}}$ \\
& Carrot & $7.35^{\mathrm{aA}}$ & $6.60^{\mathrm{bB}}$ & $5.40^{\mathrm{bC}}$ & $4.85^{\mathrm{bC}}$ \\
Texture & Cellulose & $7.35^{\mathrm{aA}}$ & $7.20^{\mathrm{abAB}}$ & $7.10^{\mathrm{aAB}}$ & $6.50^{\mathrm{aB}}$ \\
& Inulin & $7.40^{\mathrm{aA}}$ & $7.50^{\mathrm{aA}}$ & $7.40^{\mathrm{aA}}$ & $6.70^{\mathrm{aA}}$ \\
Acceptability & Carrot & $7.40^{\mathrm{aA}}$ & $6.65^{\mathrm{aB}}$ & $5.95^{\mathrm{bB}}$ & $4.70^{\mathrm{bC}}$ \\
& Cellulose & $7.40^{\mathrm{aA}}$ & $6.90^{\mathrm{aAB}}$ & $6.75^{\mathrm{abBC}}$ & $6.35^{\mathrm{aC}}$ \\
& Inulin & $7.38^{\mathrm{aAB}}$ & $7.56^{\mathrm{aA}}$ & $7.47^{\mathrm{aAB}}$ & $5.51^{\mathrm{aB}}$ \\
& Carrot & $7.38^{\mathrm{aA}}$ & $6.73^{\mathrm{bB}}$ & $5.87^{\mathrm{bC}}$ & $5.62^{\mathrm{bC}}$ \\
& Cellulose & $7.38^{\mathrm{aA}}$ & $6.75^{\mathrm{bB}}$ & $7.17^{\mathrm{aA}}$ & $6.47^{\mathrm{aC}}$
\end{tabular}

\footnotetext{
${ }^{a-c}$ Within each column, different superscript lowercase letters show differences between the fibre types within each concentration $(P<0.05)$

${ }^{A-C}$ Within each row, different superscript uppercase letters show differences between the concentrations within each fibre $(P<0.05)$
}

\section{Conclusion}

Fibre types and levels had significant effects on raw and fried chicken meatballs. Moreover, their effects on chicken meatballs caused differences during refrigerated storage. The results of the study indicated that fibres had a beneficial influence on raw and fried chicken meatballs and have potential application. They can cause differences in the properties of meatballs, depending on their sources and levels. It can be said that cellulose and carrot fibres can improve the technological properties of chicken meatballs, whereas inulin has more effect on sensory properties than the others. In particular, 3\% inulin, $9 \%$ carrot, and $6 \%$ and $9 \%$ cellulose had more beneficial effects on chicken meatballs.

\section{Acknowledgements}

The authors thank Mehmet Kaya (Social Sciences Vocational School) and Ahmet Sabri Şahin (Technical Sciences Vocational School) for their technical support.

\section{Authors' Contributions}

OK designed the study and conducted statistical analyses of the data whereas ŞK edited the draft version of the manuscript.

\section{Conflict of Interest Declaration}

The authors declare that there is no conflict of interest in this study.

\section{References}

Aleson-Carbonell, L., Fernandez-Lopez, J., Perez-Alvarez, J.A. \& Kuri, V., 2005. Characteristics of beef burger as influenced by various types of lemon albedo. Innov. Food Sci. Emerg. Technol. 6, 247-255. 
AOAC, 2002. Official methods of analysis. 17th ed. Association of Official Analytical Chemists, Washington, DC.

Biswas, A.K., Kumar, V., Bohosle, S., Sahoo, J. \& Chatli, M.K., 2011. Dietary fibres as functional ingredients in meat products and their role in human health. Int. J. Livst. Prod. 2, 45-54.

Castro, W.F., Mariutti, L.R.B. \& Bragagnolo, N., 2011. Effect of colorifico on lipid oxidation, colour and vitamin E in raw and grilled chicken patties during frozen storage. Food Chem.124,126-131.

Cava, R., Ladero, L., Cantero, V. \& Ramirez, M.R., 2012. Assessment of different dietary fibres (tomato fibre, beetroot fibre, and inulin) for the manufacture of chopped cooked chicken products. J. Food Sci. 77, 46-52.

Demirci, Z.O., Yılmaz, I. \& Demirci, A.Ş., 2014. Effects of xanthan, guar, carrageenan, and locust bean gum addition on physical, chemical, and sensory properties of meatballs. J. Food Sci. Technol. 51, 936-942.

Dhingra, D., Michael, M., Rajput, H. \& Patil, R.T., 2014. Dietary fibre in foods: a review. J. Food Sci. Technol. 49, 255266.

Dogan, I.S., 2006. Factors affecting wafer sheet quality. Int. J. Food Sci. Technol.41, 569-576.

Gokalp, H.Y., Kaya, M., Tulek, Y. \& Zorba, O., 1999. Laboratory application guide and quality control in meat and meat products. Atatürk Üniversitesi Ziraat Fakültesi, Yay No: 318, Erzurum, Turkey. (In Turkish).

Ibrahim, M.A., Salama, M.F. \& Hussein, A.A., 2011. Production of low-fat chicken burger. Aust. J. Basic Appl. Sci.5, 3149-3154.

Khalil, A.H., 2000. Quality characteristics of low-fat beef patties formulated with modified corn starch and water. Food Chem. 68, 61-68.

Kılınççeker, O., 2011. The behaviour of some vegetable-based materials used as edible coating on chicken nuggets. Food Technol. Biotechnol. 49, 237-243.

Kılınççeker, O., 2017. Tara, tragakant ve agar agar gamlarının tavuk köftelerde kullanımı. Gıda. 42, 219-228. (In Turkish).

Kılınççeker, O. \& Kurt, Ş., 2010. Effects of chickpea (Cicer arietinum) flour on quality of deep-fat fried chicken nuggets. J. Food Agric. Environ. 18,47-50.

Kılınççeker, O. \& Yilmaz, M.Y., 2016. Effects of different gums on the some properties of fried beef patties. Carpathian J. Food Sci. Tech. 8, 63-70.

Kurt, Ş. \& Kılınççeker, O., 2012. The effects of cereal and legume flours on the quality characteristics of beef patties. Kafkas Univ Vet Fak Der.18, 725-730.

McCarthy, T.L., Kerry, J.P., Kerry, J.F., Lynch, P.B. \& Buckley, D.J., 2001. Assessment of antioxidant potential of natural food and plant extracts in fresh and previously frozen pork patties. Meat Sci. 57,177-184.

Mansour, E.H. \& Khalil, A.H., 1997. Characteristics of low-fat beef burger as influenced by various types of wheat fibres. Food Res. Intern. 30,199-205.

Ockerman, H.W., 1985. pH measurement. In: Quality control of post mortem muscle tissue. 2nd ed. Ohio State University, Columbus, Ohio.

Petracci, M., Bianchi, M., Mudalal, S. \& Cavani, C., 2013. Functional ingredients for poultry meat products. Trends Food Sci. Technol. 33, 27-39.

Pinero, M.P., Parra, K., Huerta-Leidenz, N., Moreno, L.A., Ferrer, M., Araujo, S. \& Barboza, Y., 2008. Effect of oat's soluble ( $\beta$-glucan) as a fat replacer of physical, chemical, microbiological and sensory properties of low-fat beef patties. Meat Sci. 80,675-680.

Sanchez-Zapata, E., Munoz, C.M., Fuentes, E., Fernandez-Lopez, J., Sendra, E., Sayas, E.\& Navarro, C., 2010. Effect of tiger nut fibre on quality characteristics of pork burger. Meat Sci. 85, 70-76.

Santhi, D. \& Kalaikannan, A., 2014. The effect of addition of oat flour in low-fat chicken nuggets. J. Nutr: Food Sci. 4, 1-4.

Schormüller, J., 1969. Handbuch der lebensmittelchemie, band IV. Undlipoide (LIPIDS). Springer, Berlin/New York.

Serdaroğlu, M., 2006. The characteristics of beef patties containing different levels of fat and oat flour. Int. J. Food Sci. Technol. 41,147-153.

Serdaroğlu, M., Yıldız-Turp, G. \& Abrodimov, K., 2005. Quality of low-fat meatballs containing legume flours as extenders. Meat Sci. 70, 99-105.

Soltanizadeh, N. \& Ghiasi-Esfahani, H., 2015. Qualitative improvement of low meat beef burger using Aloe vera. Meat Sci. 99, 75-80.

Tabarestani, H.S.\& Tehrani, M.M., 2014. Optimization of physicochemical properties of low-fat hamburger formulation using blend of soy flour, split-pea flour and wheat starch as part of fat replacer system. J. Food Process Pres. 38, 278-288.

Talukder, S.\& Sharma, D.P., 2010. Development of dietary fibre rich chicken meat patties using wheat and oat bran. J. Food Sci. Technol. 47, 224-229.

Tarladgis, B.G., Watts, B.M. \& Younathan, M.T., 1960. A distillation method for the quantitative determination of malonaldehyde in rancid foods. J. Am. Oil Chem. 37, 44-48.

Ulu, H., 2006. Effects of carrageenan and guar gum on the cooking and textural properties of low fat meatballs. Food Chem. 95, 600-605.

Yaşarlar, E.E., Dağlıoglu, O. \& Yılmaz, I., 2007. Effects of cereal bran addition on chemical composition, cooking characteristics and sensory properties of Turkish meatballs. Asian J. Chem. 19, 2353-2361.

Yılmaz, I., 2004. Effects of rye bran addition on fatty acid composition and quality characteristics of low-fat meatballs. Meat Sci. 67, 245-249. 